\title{
Development of Worksheet Based on STEM-PBL with PhET Simulation to Improve Student's Problem Solving During the Covid-19 Pandemic
}

\author{
Arina Umu Kamila ${ }^{1, *}$ Ratih Galuh Rahmawati ${ }^{1,}$ Jumadi $^{2}$ \\ ${ }^{1}$ Master of Physics Education. Faculty of Mathematics and Natural Sciences Universitas Negeri Yogyakarta, \\ Indonesia \\ ${ }^{2}$ Department of Natural Science Education. Faculty of Mathematics and Natural Sciences Universitas Negeri \\ Yogyakarta, Indonesia \\ ${ }^{*}$ Corresponding author. Email: arinaumu.2019@student.uny.ac.id
}

\begin{abstract}
The study aims to develop worksheet based on STEM-PBL assisted by PhET simulation to improve student's problem solving during the COVID 19 Pandemic. Research development (R\&D) design used ADDIE model with stages (1) Analysis (2) Design (3) Develop (4) Implement (5) Evaluated. The subjects of this study were students of MAN 2 Yogyakarta class XI MIPA 2. In product development there were 3 tests, the validation test to the content and media experts, test practitioners to teachers, and test attractiveness to students. The results of this research indicated that develop worksheet based on STEM-PBL assisted by PhET simulation was very good considered by the experts, practitioners and students. This suggest that worksheet meet the appropriate criteria for use to improve problem solving student's during the Covid-19 pandemic.
\end{abstract}

Keywords: Worksheet, STEM-PBL, PhET Simulation, COVID-19

\section{INTRODUCTION}

A new case similar to pneumonia was first identified in Wuhan, China on 31 December 2019 [1] which spread from China to outside of China [2]. This case is known as COVID-19. According to UNESCO data, the impact of COVID-19 causes half of the student population worldwide to carry out distance learning (online learning). Indonesia is no exception. Distance learning can make it easy for students to transfer information in various situations and conditions [3]. On the other hand, it also has an impact on decreased psychological and skill quality [4]. Meanwhile, according to Minister of Education and Culture Rule No. 20 of 2016, it explains the competency standards of graduates to fulfil three dimensions, the dimensions of knowledge, attitudes, and skills. Therefore, it is necessary to have a solution in distance learning during the pandemic to continue to improve the skills of students.

Problem solving skills part of $21^{\text {st }}$ century skills [5]. Students have not maximized this skill [6], [7], even though it is an important part of learning physics
[8]. Physics learning also needs to facilitate students' problem-solving skills [9], one of which is by using the Problem Based Learning (PBL) model [10], [11]. PBL is learning that involves students in the process of solving the problems [12]. The stages in the PBL learning model include: (1) finding problems, (2) analyzing problems and studying, (3) finding and learning, (4) presenting problem solving and reflection, and (5) looking deeper into integration and evaluation by training learn independently [13].

PBL can be collaborated with STEM (Science, Technology, Engineering, Mathematic). STEM is not only focused on technology, but it includes science, technology, engineering, and mathematics [14], [15]. Science and Technology are able to encourage problem solving in everyday environments. Problems in the environment can be displayed with STEM-PBL learning to maximize learning outcomes. The implementation of STEM-PBL learning can improve problem solving skills [16].

STEM learning and PBL can be assisted with virtual media [17] one of which is the PhET (Physics 
Education Technology) simulation, using PhET as a complementary solution for the lack of physics laboratory equipment [18]. Especially distance learning does not allow students to do experiments in school. PhET media used in STEM-based can increase students' positive responses to learning [19]. Phet simulation is an attractive medium for students in independent and group learning [20], is able to emphasize the relationship between real life and science, supports interactive, creative learning, provide feedback [21], and can support the distance learning (online) [22] we are currently experiencing.

STEM-PBL-based learning assisted by PhET simulation can be written in a learning medium. STEM, PBL and PhET simulation can be juxtaposed with worksheets [23]. Worksheets is one of the learning tools that help and support the implementation of lesson plans (RPP). In addition, student worksheets can be used as a means to increase the effectiveness of learning, train students' abilities in thinking, acting, and behaving [24] and guiding students to develop concepts. Worksheets is one of the supporting learning media during the pandemic period [25]. So that learning during the COVID-19 pandemic can be helped by worksheets based on STEM-PBL assisted by PhET simulation.

\section{RESEARCH METHOD}

\subsection{Type of Research}

The design of research is research and development (R\&D) with ADDIE model. The ADDIE model used has stages (1) Analysis (2) Design (3) Develop (4) Implement (5) Evaluated. The ADDIE model stages can be seen in Figure 1

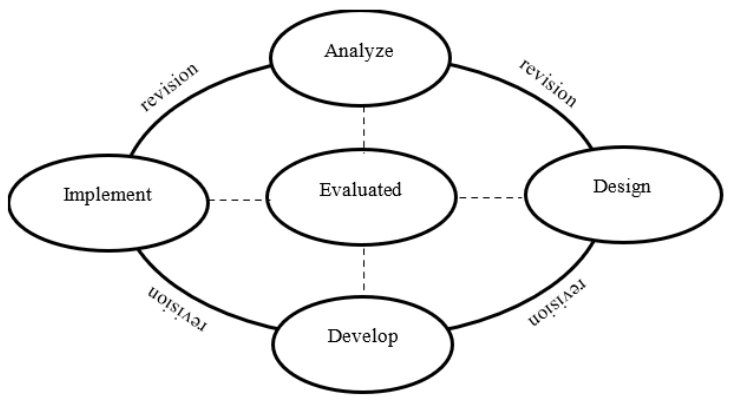

Figure 1 ADDIE model product development stage.

\subsubsection{Analysis}

Analysis is the initial stage for identifying problems, needs, and tasks. This analysis was carried out by means of observation and interviews, the results of which were used as reference materials for product development.

\subsubsection{Design}

Based on needs analysis result, then design / design by selecting materials, collecting materials such as images / videos used in product development and other supporting sources.

\subsubsection{Implement}

This stage produces worksheets that has been assessed for feasibility by experts. Furthermore, the assessment by the teacher and students each filled out the practitioner sheet and student response sheet. This sheet serves to see the responses of teachers and students to the products being developed.

\subsubsection{Evaluated}

The evaluation stage is carried out to evaluate the LKPD products as a learning medium. In addition, evaluations are also carried out at every four stages in the ADDIE model which is called formative evaluation. It aims to need revision at each stage of development.

\subsection{Research Subject}

The subjects of this study were students of MAN 2 Yogyakarta in the 2019/2020 academic year class XI MIPA 2.

\subsection{Data Analysis Techniques}

Non-test instruments in the form of expert validation instruments are the instruments content and media, the instruments of practitioners and response instruments to students.

The data analysis technique used is the feasibility and practicality analysis using a 1-4 Likert scale in Table 1

Table 1. Categories of the Likert scale rating criteria

\begin{tabular}{|l|l|}
\hline Scale & Note \\
\hline 4 & Very much agree \\
\hline 3 & Agree \\
\hline 2 & Don't agree \\
\hline 1 & Disagree \\
\hline
\end{tabular}

The percentage of student validation scores and responses uses the formula: 


$$
\mathrm{P}=\frac{\text { score obtained }}{\text { score } \max } \times 100 \%
$$

After getting the percentage score of each aspect of the product, then the decision-making criteria can be seen in Table 2

Table 2. Decision making criteria

\begin{tabular}{|c|c|}
\hline Skor & Criteria \\
\hline $81-100 \%$ & Very good \\
\hline $61-80 \%$ & Good \\
\hline $41-60 \%$ & Less good \\
\hline $21-40 \%$ & Not good \\
\hline
\end{tabular}

\section{RESULT AND DISCUSSION}

Worksheets was developed based on the results of observations and interviews with teachers and students of class XI MIPA 2 at MAN 2 Yogyakarta. The results obtained were (1) during the Covid-19 pandemic students found it difficult to learn physics. (2) Students are more interested and easier to understand with experiments learning. (3) students better understand physics material when it is linked in everyday life. (4) students have not been maximal in solving existing problems, sometimes students have not been able to solve questions (5) there is no media that supports learning with these four problems.

The teacher's solution in learning during the Covid-19 pandemic was by using the WhatsApp media as the application most used by students to communicate. The teacher sometimes presents problems in learning to lead students to learn and solve problems, but students still have difficulty solving them. During the pandemic teachers have not conducted laboratory experiments due to regulations requiring distance learning. Therefore, it requires learning media that supports the Covid-19 pandemic, supports experiments without having to go to school laboratories, as well as learning media that is able to display and students are able to solve problems in everyday life.

The first step in product development is design. The design of the worksheets is done by collecting material sources, pictures and other sources. Basic Competencies used are 3.10 and 4.10 in light wave material. Then combine all the materials using Corel Draw X7, Photoshop, Microsoft Word so that a worksheet is generated. The application of STEM, PBL, and the stages of learning activities in worksheets is shown in Tables 3 and 4.
Table 3. Application of STEM in learning

\begin{tabular}{|l|l|}
\hline Component & Explanation \\
\hline Science & Reflection and refrection of light \\
\hline Technology & $\begin{array}{l}\text { The use of PhET Simulation } \\
\text { (light waves) and the use of e- } \\
\text { learning }\end{array}$ \\
\hline Engineering & $\begin{array}{l}\text { Designing simple light } \\
\text { refraction }\end{array}$ \\
\hline Mathematics & Calculation with Snellius Law \\
\hline
\end{tabular}

Table 4. Application of STEM in learning

\begin{tabular}{|l|l|}
\hline Step & Syntax in PBL \\
\hline 1 & $\begin{array}{l}\text { Student are given a light wave } \\
\text { phenomenon in the form of a rainbow }\end{array}$ \\
\hline 3 & $\begin{array}{l}\text { Student identify the rainbow phenomenon } \\
\text { that is displayed }\end{array}$ \\
\hline 4 & $\begin{array}{l}\text { Student conduct a light wave experiment } \\
\text { exing a PhET simulation. }\end{array}$ \\
\hline 5 & $\begin{array}{l}\text { Students present the results of } \\
\text { of experiments that havents questions on the worksheets } \\
\text { as well as conducting joint evaluations with } \\
\text { the teacher }\end{array}$ \\
\hline
\end{tabular}

The resulting product then validated by a validator (expert). The validity test is carried out to determine the feasibility of the product being developed. There are two validations, material and media validation, each consists of two validators. After the revision was made, the worksheets product was produced. Worksheets display can be seen in Figure 2.

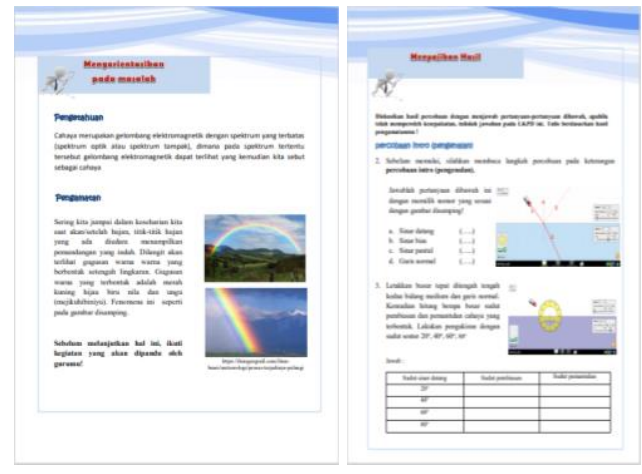

Figure 2 Display of worksheets. 
Table 5. Expert validation results

\begin{tabular}{|c|c|c|c|}
\hline \multirow{2}{*}{ Expert } & Aspect & $\begin{array}{c}\% \text { final } \\
\text { score }\end{array}$ & Category \\
\hline \multirow{2}{*}{ Material } & $\begin{array}{c}\text { Feasibility } \\
\text { content }\end{array}$ & $84,09 \%$ & Very good \\
\cline { 2 - 4 } & Linguistic & $75,00 \%$ & Very good \\
\cline { 2 - 4 } & $\begin{array}{c}\text { Presen- } \\
\text { tation }\end{array}$ & $82,14 \%$ & Very good \\
\hline Media & Graphic & $82.63 \%$ & Very good \\
\hline Average & $87,52 \%$ & $81,48 \%$ & Very good \\
\hline
\end{tabular}

The result of expert validation shows that almost all aspects get very valid values except for linguistic aspects. In the aspect of content feasibility, the percentage of the final score was the largest, $84.09 \%$ with the very good category. The linguistic aspect gets the lowest score percentage, $75.00 \%$ with good category. From all aspects obtained an average final score of $81.48 \%$ in the very good category. This result indicated that worksheet based on STEM-PBL assisted by PhET simulation was very good/very valid considered by the experts.

Indicators in the appropriateness of the content include compatibility with K13, basic competencies, learning indicators, learning objectives, suitability with the models and approaches used, and their suitability in improving student problem solving skills. This is same with [26] that the worksheet component is one of them in the form of student activities such as practicum and extra content according to the orientation of basic competencies and achievement indicators, so that it is expected to be able to improve students' understanding through experience.

The linguistic aspect gets the lowest score out of the other three aspects because (1) there are still words/sentences that are not in accordance with EYD (2) the choice of words/sentences is inaccurate (3) inaccurate use of punctuation marks (4) the instructions in the PhET simulation are not well described. In the linguistic aspect, the language should be straightforward, communicative, dialogical and interactive, according to the level of development, clutter, and an integrated line of thought, and the use of terms and symbols [27]. The symbols and symbols used must also be consistent so as not to confuse and confuse students. [28]. The graphic aspect is in accordance with [27] that worksheets must match the module size, cover design and module content design.

After the worksheet's validation to the experts then the practitioner test. This test was conducted by two physics teachers. The practitioner test consists of four aspects (1) feasibility of content (2) linguistics, (3) presentation, and (4) graphic. The results of the practitioner's test are displayed in the mean percentage of the final score as in Table 6.

Table 6. Test practitioners.

\begin{tabular}{|l|l|l|}
\hline Aspect & $\begin{array}{l}\text { Percentage final } \\
\text { score }\end{array}$ & Category \\
\hline $\begin{array}{l}\text { Feasibility } \\
\text { content }\end{array}$ & $89,76 \%$ & Very good \\
\hline Linguistic & $87,83 \%$ & Very good \\
\hline Presentation & $85,71 \%$ & Very good \\
\hline Graphic & $86,80 \%$ & Very good \\
\hline Average & $87,52 \%$ & Very good \\
\hline
\end{tabular}

The results of the practitioner's test showed that all aspects were in very good category. The highest score on the content feasibility aspect was $89.76 \%$ and the lowest score percentage in the presentation aspect was $85.71 \%$. The average of all aspects is $87.52 \%$ with very good category. This result indicated that worksheet based on STEM-PBL assisted by PhET simulation was very good considered by the practitioners.

The student response test consists of two aspects the attractiveness and ease of the product. Student response tests can be seen in table 7 . The two aspects are attractiveness and ease of getting very good category with scores of $89.16 \%$ and $91.66 \%$. The average of attractiveness and ease are $90,41 \%$ with very good category. This result indicated that worksheet based on STEM-PBL assisted by PhET simulation was very good considered by student response.

Table 7. Test student responses

\begin{tabular}{|l|l|l|}
\hline Aspect & $\begin{array}{l}\text { Percentage final } \\
\text { score }\end{array}$ & Category \\
\hline Attractiveness & $89,16 \%$ & Very good \\
\hline Ease & $91,66 \%$ & Very good \\
\hline Average & $90,41 \%$ & Very good \\
\hline
\end{tabular}

\section{CONCLUSION}

The conclusion obtained that worksheet based on STEM-PBL assisted by PhET simulation was very good considered by the experts, practitioners and students respons. The expert validation test was in the very good category with an average score of $81.48 \%$. The practitioners test gets an average score of $87.52 \%$ with the very good category. The student respons test 
got a score of $89.16 \%$ with the very good category. This suggest that worksheet meet the appropriate criteria for use to improve problem solving student's during the Covid-19 pandemic

\section{REFERENCES}

[1] A. Lee, Wuhan Novel Coronavirus (COVID-19): Why Global Control Is Challenging? Public Health 179 (2020) A1-A2. DOI: https://dx.doi.org/10.1016\%2Fj.puhe.2020.02.00 $\underline{1}$

[2] Z.Y. Zu, M.D. Jiang, P.P.Xu, W. Chen, Q.Q. Ni, G.M. Lu, L.J. Zhang, Corona Disease 2019 (COVID-19): A Prespective from China. Radiology 296(2) (2020) 15-25. DOI: https://doi.org/10.1148/radiol.2020200490

[3] L.D. Herliandry, Nurhasanah, M.E. Suban, H. Kuswanto, Pembelajaran pada Masa Pandemi COVID-19, Jurnal Teknologi Pendidikan 22(1) (2020) 65-70. DOI: https://doi.org/10.21009/jtp.v22i1.15286

[4] R. H. S. Aji. Dampak COVID-19 pada Pendidikan di Indonesia: Sekolah, Keterampilan, dan Proses Pembelajaran, Jurnal Sosial \& Budaya Syar'i 7(5) (2020) 395-402. DOI: https://doi.org/10.15408/sjsbs.v7i5.15314

[5] J. Agung, D.H. Putri, H. Johan, Idenfifikasi Pembekalan Keterampilan Abad 21 pada Aspek Keterampilan Pemecahan Masalah Siswa SMA Kota Bengkulu dalam Mata Pelajaran Fisika, Jurnal Kumparan Fisika 3(1) (2020) 25-32. DOI: https://doi.org/10.33369/jkf.3.1.25-32

[6] R. Yustianingsih, H. Syariffudin, Yeziron. Pengembangan Perangkat Pembelajaran Matematika Berbasis Problem Based Learning (PBL) untuk Meningkatkan Kemampuan Pemecahan Masalah Peserta Didik Kelas VII, Jurnal Nasional Pendidikan Matematika 1(2) (2017) 258-274. DOI: http://dx.doi.org/10.33603/jnpm.v1i2.563

[7] D. Ratnaningdyah, Penerapan Model Pembelajaran Novick Dipadukan dengan Strategi Cooperative Problem Solving (CPS) untuk Meningkatkan Kemampuan Pemecahan Masalah Siswa SMA, Jurnal Wahana Pendidikan Fisika 2(2) (2017) 63-67. DOI: https://doi.org/10.17509/wapfi.v2i2.5043

[8] J.L. Docktor., J.P. Mestre, Synthesis of Discipline Based Education Research in Physics,
Physical Review Special Topics Physics Educational Research 10(2) (2014) 1-58. DOI: https://doi.org/10.1103/PhysRevSTPER.10.0201 $\underline{19}$

[9] A. Mason, C. Singh, Surveying Graduate Students Attitudes and Approaches to Problem Solving, Physical Review Special Topics Physics Educational Research 6(2) (2010) 020124. https://doi.org/10.1103/PhysRevSTPER.6.02012 $\underline{4}$

[10] F. Fatimah. Kemampuan Komunikasi Matematis dan Pemecahan Masalah Melalui Problem Based Learning, Jurnal Penelitian dan Evaluasi Pendidikan 16(1) (2012) 249-259. DOI: https://doi.org/10.21831/pep.v16i1.1116

[11] R. Sariningsih, R. Purwasih, Pembelajaran Problem Based Learning untuk Meningkatkan Kemampuan Pemecahan Masalah Matematis dan Self Efficacy Mahasiswa Calon Guru, Jurnal Nasional Pendidikan Matematika 1(1) (2017) 163-177.

DOI: http://dx.doi.org/10.33603/jnpm.v1i1.275

[12] R.I. Arends \& A. Kilcher Teaching for Student Learning Become An Accomplished Teacher, Routledge, 2009.

[13] O.S. Tan, Enhancing Think Though Problem Based Learning Approaches, Thomson Learning, 2004.

[14] C.D. Allen, M. Eisenhart. Fighting for Desired Versions of A Future Self: How Young Women Negotiated STEM-Related Identities in the Discursive Landscape of Educational Opportunity, Journal of the Learning Sciences 26(3) (2017) 407-36. DOI: https://doi.org/10.1080/10508406.2017.1294985

[15] N. Khoiriyah, Abdurrahman, I. Wahyudi. Implementasi Pendekatan Pembelajaran STEM untuk Meningkatkan Kemampuan Berfikir Kritis Siswa SMA pada Materi Gelombang Bunyi, Jurnal Riset dan Kajian Pendidikan Fisika 5(2) (2018) 53-62. DOI: http://dx.doi.org/10.12928/jrkpf.v5i2.9977

[16] L. Iolanessa, I. Kaniawati, M. G. Nugraha. Pengaruh Model Problem Based Learning (PBL) Menggunakan Pendekatan STEM dalam Meningkatkan Keterampilan Pemecahan Masalah Siswa SMP, WaPFI Wahana Pendidikan Fisika 5(1) (2020) 113-117. DOI: https://doi.org/10.17509/wapfi.v5i1.23452 
[17] A. Hastuti, H. Sahidu, Gunawan, Pengaruh Model PBL Berbantuan Media Virtual Terhadap Kemampuan Pemecahan Masalah Fisika. Jurnal Pendidikan fisika dan Teknologi 2(3) (2016) 129135.

DOI:

http://dx.doi.org/10.29303/jpft.v2i3.303

[18] I Yusuf, S.W. Widyaningsih, HOTS Profile of Physics Education Students in STEM-Based Classes using PhET Media, in: Journal of Physics Conference Series, vol. 1157, IOP Publishing, Bristol, 2019, pp. 1-6. DOI: http://doi.org/10.1088/17426596/1157/3/032021

[19] K.K. Perkins, E.B. Moore, S.V. Chasteen. Examining the use of PhET Interactive Simulation in US Collage and High School Classrooms, in: PERC Proceedings, vol. 10, American Association of Physics Teachers, College Park, Maryland, 2015, pp. 207-210. DOI.: https://doi.org/10.1119/perc.2014.pr.048

[20] S. Prihatiningtyas, T. Prastowo, B. Jatmiko. Imlementasi Simulasi PhET dan KIT Sederhana untuk Mengajarkan Keterampilan Psikomotor Siswa pada Pokok Bahasan Alat Optik, Jurnal Pendidikan IPA Indonesia 2(1) (2013) 18- 22. DOI: https://doi.org/10.15294/jpii.v2i1.2505

[21] Finkelstein, N, W. Adams, C. Keller, K. Perkins, C. Wieman High-Tech Tools for Teaching Physics: The Physics Education Technology Project, Merlot Journal of Online Learning and Teaching 2(3) (2006) 110-121.

[22] E. Dewa, M.J.M. Ursula, O. Pandago, Pengaruh Pembelajaran Daring Berbantuan Laboratorium Virtual Terhadap Minat dan Hasil Belajar Kognitif Fisika, Jurnal Riset Teknologi dan Inovasi Pendidikan 3(2) (2020) 351-359. DOI: http://doi.org/10.36765/jartika.v3i2.288

[23] F. Sarnita, A. Fitria, Widia. Pengembangan Perangkat Pembelajaran Model PBL Berbasis STEM untuk Melatih Keterampilan Berfikir Kreatif Siswa Tuna Netra, Jurnal Pendidikan MIPA 9(1) (2019) 38-44. DOI: https://doi.org/10.37630/jpm.v9i1.180

[24] M. Kaleka., Y. Ika. Developing The CharacterBased Students Worksheet of Science with Inquiry Model for Students of Grade IX, Journal of Science Educational Research 2(2) (2018) 6670.

DOI:
[25] A.R. Setiawan, Lembar Kegiatan Literasi Saintifik untuk Pembelajaran Jarak Jauh Topik Penyakit Coronavirus 2019 (COVID-19), Jurnal Edukatif 2(1) (2020) 28-37. DOI: https://doi.org/10.31004/edukatif.v2i1.80

[26] R.A. Pratama, A. Saregar. Pengembangan Lembar Kerja Peserta Didik (LKPD) Berbasis Scafolding untuk Melatih Pemahaman Konsep, Indonesia Journal of Science and Mathematics Education 2(1) (2019) 84-97. DOI: https://doi.org/10.24042/ijsme.v2i1.3975

[27] Zainudin, Pengembangan E-Learning Fisika Menggunakan PhET (Physics Educational Technology) pada Materi Pokok Dinamika Gerak Lurus Berbasis Keterampilan Berfikir Kritis, Jurnal Pena Sains 4(1) (2017) 22-33. DOI: https://doi.org/10.21107/jps.v4i1.2777

[28] J. Budaeng, H.D. Ayu, H.Y. Pratiwi, Pengembangan Modul IPA Fisika Terpadu Berbasis Scaffolding pada Tema Gerak untuk Siswa Kelas VIII SMP/MTs, Physics Educational Journal 1(1) (2017) 31-44. DOI: https://doi.org/10.21067/mpej.v1i1.1633 https://doi.org/10.21831/jser.v2i2.22470 